\title{
Anatomical investigation of root, stem and branch wood in 10-year-old Inga laurina in the context of anatomical adaptation to hydraulic and mechanical stresses
}

\author{
Eduardo L. Longui ${ }^{1}$, Ana T. D. Galão ${ }^{1}$ Kishore S. Rajput² \& Antônio C. G. de Melo \\ 1 Instituto Florestal, CEP 02377-000, São Paulo, SP, Brazil. \\ 2 Department of Botany, Faculty of Science, The Maharaja Sayajirao University of Baroda, Vadodara 390002, India.
}

\section{Correspondence}

E.L. Longui

E-mail: edulongui@gmail.com

Received: 5 September 2017

Accepted: 5 February 2018

Published on-line: 7 March 2018

\section{Resumen}

Investigación anatómica de la madera de la raíz, el tallo y la rama en ejemplares de 10 años de edad de Inga laurina en el contexto de la adaptación anatómica al estrés hidráulico y mecánico

La madera varía entre las especies, desde la médula hasta la corteza, desde las raíces hasta la corona dentro de la misma planta, para garantizar la seguridad y la eficiencia hidráulica. La heterogeneidad de la madera de Inga laurina (Sw.) Willd. es aquí investigada, siendo una especie que prospera bien en todos los bosques brasileños importantes. La madera de tallo de I. laurina poseía vasos estrechos; fibras de paredes gruesas; rayos más anchos, altos y en mayor frecuencia, características que proporcionan ajustes hidráulicos y mecánicos. Las fibras de paredes gruesas y menos parénquima, en comparación con la raíz, brindan la fuerza suficiente para apoyar la corona grande. Una mayor proporción de células de parénquima en las raíces da como resultado una gran capacidad de almacenamiento de almidón, que es importante para la recuperación de los brotes después del daño por fuego, común en el Cerrado.

Palabras clave: Cerrado, Conductividad hidráulica, Densidad, Estructura arbórea, Madera tropical o subtropical.

\begin{abstract}
Wood varies between species, from pith to bark, roots to crown within the same plant to ensure hydraulic safety and efficiency. Inga laurina (Sw.) Willd. is investigated herewith for the structural heterogeneity of the wood, since this species thrives well in all major forests of Brazil. I. laurina stem wood possessed narrow vessels; thick walled fibres; wider, taller and higher frequency of rays, features that provide hydraulic and mechanical adjustments. Thick walled fibres and less parenchyma as compared to root provide enough strength to stem to support the large crown. Higher proportion of parenchyma cells in roots results in a high storage capacity for starch, which is important for the shoot recovery after fire damage, common in the Cerrado.
\end{abstract}

Key words: Cerrado, Hydraulic conductivity, Density, Tree structure, Tropical or subtropical wood. 


\section{Introduction}

Inga laurina (Sw.) Willd. (Fabaceae) is a native species of Brazil (Pennington 1997, Garcia 1998). It is distributed from north to south of Amazon, in Caatinga, Cerrado and Atlantic Rainforest. It also grows naturally in Rupestrian Field, Semi-deciduous Forest, Ombrophylous Forest and Restinga (Garcia \& Fernandes 2014). Typically, this species is found on river margins or on dry fields, as well as interfluve regions of the Cerrado (Pennigton 1997) and in gaps in the Amazonian Forest (Souza et al. 2011). In all these forests, amount of annual precipitation varies from region to region, yet the present species thrives well in all these forest types.

Structurally, the secondary xylem is heterogeneous (i.e. non-uniform); particularly variation in xylem structure from pith to bark, root to apical meristem, and from stem to branch. Therefore, this heterogeneity in the secondary xylem structure results in spatial variation in hydraulic and mechanical performance of the xylem (Gartner 1995). For instance, concerning hydraulic efficiency and mechanical strength trade-off, high frequency of large vessels has positive influence on hydraulic efficiency and negative influence on mechanical strength (Baas et al. 2004). In contrast, variation in abiotic and biotic environments often compels trees to respond through growth rate like height, stem diameter, canopy cover, and root depth (Hinckley et al. 2011) to compete for above and below ground resources.

Recent studies are focused on the structural variation in the axial conducting elements of plants, which attempt to explain how xylem structure provides hydraulic safety and water conducting efficiency from roots to leaves for plants growing under higher salinity, water limitation or high levels of rainfall variability, and in droughttolerant conditions (Robert et al. 2009, von Arx et al. 2012, Abrantes et al. 2013, Anfodillo et al. 2013).

Such findings open up a vast field for new research into the axial variations of vessels and tracheids a as water conducting cells and variations in fibers and parenchyma cells that together forms the wood structure. Thus, it is challenging to the wood researchers to focus their attention on plant species living under different conditions, whether in natural forests or artificial forest plantings. Present study anatomically investigated the variation in the hydraulic conductivity and wood density of I. laurina wood at different positions viz. root, main stem and branch. We hypothesize that I. laurina, a species with a large crown is able to adjust its stem wood to perform necessary functions that are associated with hydraulic conductivity. However, available literature indicates that trees are able to regulate one parameter without affecting the other that is associated with former one (Awad et al. 2012, Badel et al. 2015).

\section{Material and methods}

\section{Study area}

The study was carried out in the Cerrado area of

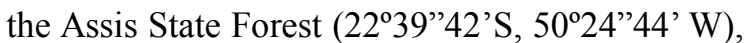
Assis, São Paulo (Max et al. 2007). According to Bognola et al. (2003), the soil in this region has low organic matter with good permeability and good water holding capacity. The climate is Cwa by the Köppen climate classification: warm with dry winters, mean annual temperature of $20^{\circ} \mathrm{C}$, mean maximum of $25^{\circ} \mathrm{C}$ and average minimum is of $18{ }^{\circ} \mathrm{C}$. The average annual rainfall is 1441.5 $\mathrm{mm}$ (CEPAGRI 2017). The region has a dry season between April and September (see Fig. 1).

\section{Sampling}

Transplantation of I. laurina planting was established in 2002 at a distance of $3 \mathrm{~m} \mathrm{x} 2 \mathrm{~m}$. After 10 years, 11 trees were felled and circular discs of the root at $0.3 \mathrm{~m}$ depth from ground level and above ground samples were obtained from two different positions i.e. at $0.5 \mathrm{~m}$ (stem) and $1.5 \mathrm{~m}$ i.e. from main branch (branch which forked more centrally in relation to the stem) in height (Fig. 2 and Table 1).

\section{Wood anatomy, hydraulic conductivity and density}

Small wood pieces (outermost 2-3 yrs. growth increment) adjacent to bark were cut from the four different sides of the disc that were obtained from roots, stem and branches. Thin slices of wood material were obtained with the help of razor blade and macerated according to the modified Franklin method (Berlyn \& Miksche 1976) to obtain dimensional details of the individual wood elements. Thirty measurements were taken randomly to obtain mean and standard deviations. For sectioning, as mentioned above, outermost 2- 


\begin{tabular}{lccccccccccc}
\hline Tree $^{\circ}$ & $\mathbf{1}$ & $\mathbf{2}$ & $\mathbf{3}$ & $\mathbf{4}$ & $\mathbf{5}$ & $\mathbf{6}$ & $\mathbf{7}$ & $\mathbf{8}$ & $\mathbf{9}$ & $\mathbf{1 0}$ & $\mathbf{1 1}$ \\
\hline Tree height $(\mathrm{m})$ & 6.2 & 6.2 & 6.4 & 6.2 & 6.3 & 6.0 & 5.5 & 5.7 & 5.2 & 5.8 & 6.3 \\
\hline$\varnothing 1.5 \mathrm{~m}(\mathrm{~cm})$ Main branch & 8.5 & 7.1 & 9.9 & 9.7 & 9.0 & 7.2 & 5.0 & 6.4 & 4.7 & 7.8 & 7.5 \\
$\varnothing 0.5 \mathrm{~m}(\mathrm{~cm})$ Stem & 11.8 & 11.6 & 12.6 & 11.7 & 12.5 & 10.5 & 7.9 & 8.8 & 6.3 & 9.1 & 12.4 \\
$\varnothing$ Root $(\mathrm{cm}) 30 \mathrm{~cm}$ depth & 3.6 & 5.3 & 4.6 & 3.8 & 9.8 & 5.7 & 4.9 & 8.3 & 5.8 & 4.0 & 4.7 \\
\hline
\end{tabular}

Tabla 1. Altura del árbol y diámetro de la raíz, tallo y rama principal de Inga laurina con 10 años de edad.

Table 1. Tree height and diameter of root, stem and main branch of 10-year-old Inga laurina.

A
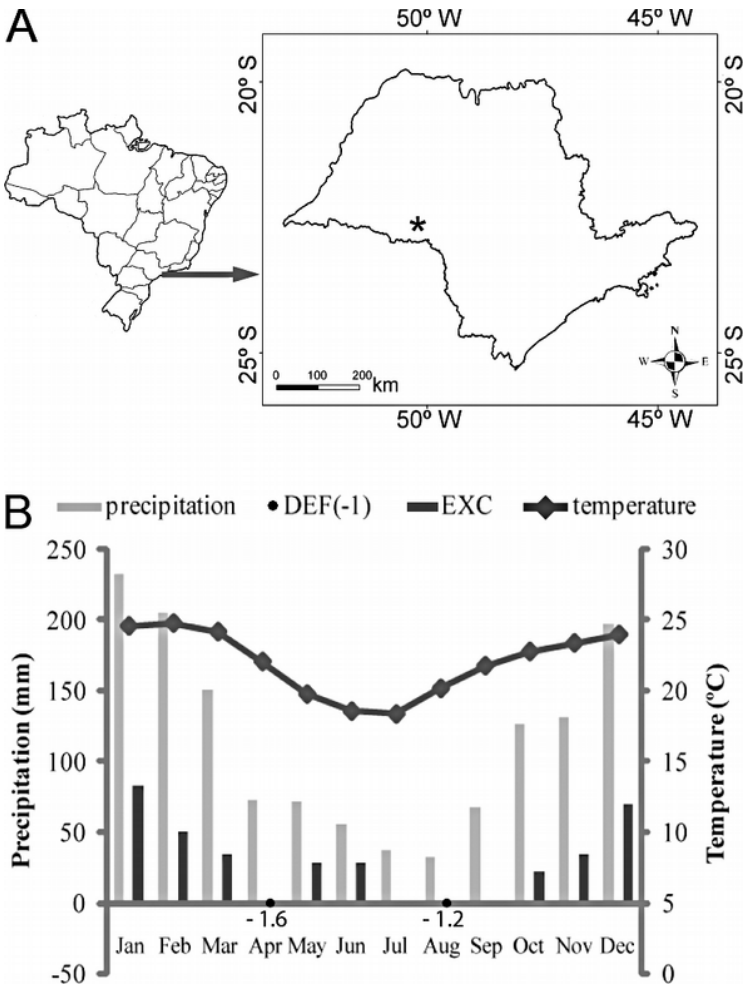

Figura 1. A: Localización del Bosque Estatal de Assis (*) en el Estado de São Paulo, Brasil; B: Precipitación media mensual, déficit hídrico DEF(-1) (abril y agosto), excedente hídrico EXC y temperatura media en el Bosque Estatal de Assis desde 1961a 1990 (CEPAGRI, 2017).

Figure 1. A: Location of Assis State Forest (*) in São Paulo State, Brazil; B: Mean monthly precipitation, water deficit DEF(1) (April and August), water surplus EXC and mean temperature at Assis State Forest from 1961-1990 (CEPAGRI, 2017).

3 year's wood increments were cut from the four opposite sides of all 11 wood disks each that were obtained from root, stem and branches (total 33 wood disks). These wood pieces were boiled for $60 \mathrm{~min}$ in water: glycerin: alcohol $(4: 1: 1)$ to soften the wood. Transverse, tangential and radial longitudinal sections of 14-18 $\mu \mathrm{m}$ thick were cut using a sledge microtome. They were stained with a $1 \%$ aqueous solution of safranin and subsequently washed with water and mounted in water and glycerin (1:1) solution on slides.

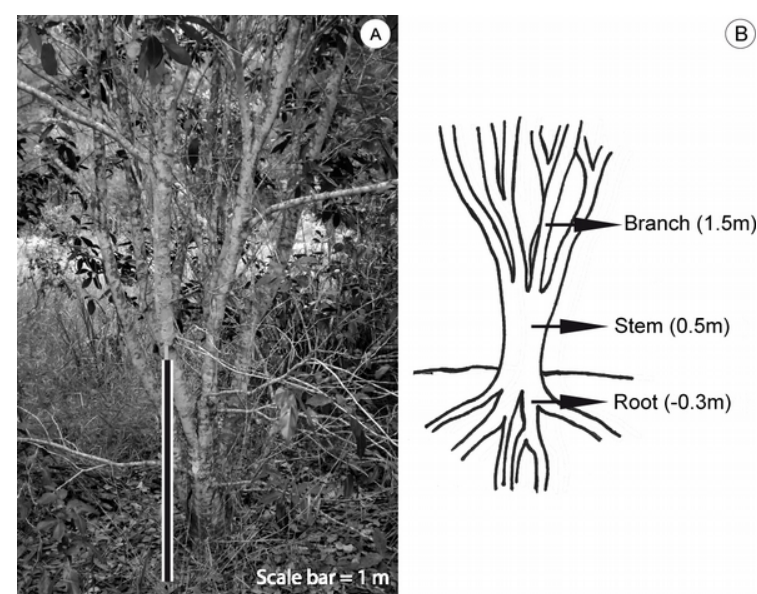

Figura 2. A: Árbol de Inga laurina y muestreo; B: Ilustración esquemática que muestra los puntos de extracción de las muestras de madera para su investigación.

Figure 2. A: Inga laurina tree and sampling; B: Schematic illustration showing the points of removal of wood samples for investigation.

The terminology and characterization of wood is followed as per the IAWA list (IAWA Committee 1989). All anatomical measurements were obtained using an Olympus CX 31 microscope equipped with a digital camera (Olympus Evolt E 330) and image analyzer software (Image-Pro $6.3)$.

Vessel grouping index was calculated as described by Carlquist (2001) and according to the equation of Scholz et al. (2013): Vg $=\mathrm{N}$ vessels/N groupings, where $\mathrm{Vg}=$ vessel grouping and groupings $=$ solitary, multiples of 2, 3 and multiples of 4 or more vessels. We also calculated the percentage of various cell types (fiber, vessel, axial parenchyma and ray) by plotting 25 points randomly in an area of $1 \mathrm{~mm}^{2}$ and performing at least 25 measurements on each sample. From values of vessel diameter and vessel density, we calculate the potential hydraulic conductivity $\left(\mathrm{K}_{\mathrm{p}}\right)$ (first equation) according to the Hagen-Poiseuille law described by Sterck et al. (2008) and Poorter et al. (2010). We used two equations in this step: 


$$
K_{p}=\left(\frac{\pi \rho_{w}}{128 \eta}\right) \times V D \times D_{h}^{4}
$$

$K_{p}=$ potential hydraulic conductivity (in $\mathrm{kg} \mathrm{m} \mathrm{MPa}^{-1} \mathrm{~s}^{-1}$ ); $\rho_{\mathrm{w}}=$ water density at $20^{\circ} \mathrm{C}\left(998.2 \mathrm{~kg} \mathrm{~m}^{-3}\right) ; \eta=$ viscosity index of water $\left(1.00210^{-6} \mathrm{MPa} \mathrm{s}^{-1}\right.$ at $\left.20^{\circ} \mathrm{C}\right)$, VD = vessel density (cells $\mathrm{m}^{-2}$ ) and $D_{h}=$ vessel hydraulic diameter $(\mathrm{m})$.

Since vessels are not exactly circular, we calculate vessel hydraulic diameter from second equation, from diameter of each vessel as the mean of the minimum and maximum diameters. The average Dh was calculated as (Sterck et al. (2008) and Poorter et al. (2010):

$$
D_{h}=\left[\left(\frac{1}{n}\right) \sum_{i=n}^{n} d^{4}\right]^{1 / 4}
$$

$\mathrm{n}=$ number of vessels and $\mathrm{d}=$ vessel diameter.

Wood density ( $\rho 12)$ was determined according to Glass and Zelinka (2010) evaluating the mass and volume at $12 \%$ moisture content (MC). Specimens $2 \times 2 \times 3 \mathrm{~cm}$ were conditioning at constant temperature and $\mathrm{MC}\left(21^{\circ} \mathrm{C}\right.$ and $65 \% \mathrm{MC}$, respectively) and, in this condition, mass was determined with analytical balance and the volume estimated by means of measurements of their dimensions with caliper rule.

\section{Statistics}

Descriptive statistical analysis was initially performed by considering all axial positions. Followed by Normality Test was performed to observe the data distribution. Based on parametric analysis of variance (One Way Analysis of Variance), when a normal distribution of data was not observed; data were transformed (i.e. square roottransformed). In the case of a significant difference, Tukey's test was applied to identify pairwise determinants of differences. Results with $\mathrm{p}<0.01$ were considered as significant.

\section{Results}

Vessel diameter and its frequency are directly re- lated with each other. The mean vessel diameter was wider in the root than stem and branches wood (Table 2). Its frequency was higher in both stem and main branch while it was lower in root wood (Fig. 3). Vessel grouping index followed the vessel frequency variation and hydraulic conductivity followed the vessel diameter variation. Length of the xylem fibers was higher in root and shorter in wood discs at $1.5 \mathrm{~m}$ (main branch), while their walls were thick in the wood obtained at $0.5 \mathrm{~m}$ height of the trees. Xylem rays were mostly uni-biseriate, their height, width and frequency were higher at $0.5 \mathrm{~m}$, shorter and thin walled rays were observed in the root while their height and frequency were less at $1.5 \mathrm{~m}$. Compared to branches and roots, density of wood was higher in stem (Table 2).

A higher proportion of fibers were observed in stem and branch, irrespective of height. The percentage of vessels did not vary between root and stem or branch. A higher proportion of axial parenchyma occurred at the root (Fig. 4). Vessels were mostly solitary in root as compared to stem or branch which showed mostly multiples while their frequency remained similar in stem and branch wood. Geminate vessels did not vary between root and stem. Vessel multiples of 3 gradually increased from the root towards branch in all the samples investigated. Vessel multiples of 4 were higher in stem and branch, but multiples were relatively less in the root xylem (Fig. 5). A negative relationship was observed between density and vessel diameter (Fig. 6).

\section{Discussion}

Hydraulic architecture can be studied in terms of the tradeoff between safety and efficiency. In this context, it was found that I. laurina root is more efficient in transporting water because it has larger diameter vessels compared to those of stem or branch results that coincide to Schuldt et al.

\begin{tabular}{lcccccccccc} 
Wood Features & VD & VF & Vg & $\boldsymbol{K}_{\mathbf{p}}$ & $\mathbf{F L}$ & $\mathbf{F W T}$ & $\mathbf{R H}$ & $\mathbf{R W}$ & $\mathbf{R F}$ & $\mathbf{( \rho 1 2 )}$ \\
\hline Branch $(1.5 \mathrm{~m})$ & $130 \mathrm{~b}$ & $7 \mathrm{a}$ & $1.7 \mathrm{a}$ & $75.0 \mathrm{~b}$ & $1006 \mathrm{c}$ & $6 \mathrm{~b}$ & $253 \mathrm{~b}$ & $21 \mathrm{~b}$ & $8 \mathrm{c}$ & $0.87 \mathrm{a}$ \\
Stem $(0.5 \mathrm{~m})$ & $122 \mathrm{c}$ & $7 \mathrm{a}$ & $1.6 \mathrm{a}$ & $69.4 \mathrm{c}$ & $1205 \mathrm{~b}$ & $7 \mathrm{a}$ & $283 \mathrm{a}$ & $33 \mathrm{a}$ & $10 \mathrm{a}$ & $0.85 \mathrm{a}$ \\
Root $(30 \mathrm{~cm})$ & $139 \mathrm{a}$ & $5 \mathrm{~b}$ & $1.4 \mathrm{~b}$ & $81.5 \mathrm{a}$ & $1314 \mathrm{a}$ & $6 \mathrm{~b}$ & $232 \mathrm{c}$ & $18 \mathrm{c}$ & $9 \mathrm{~b}$ & $0.71 \mathrm{~b}$ \\
\hline
\end{tabular}

$\mathrm{VD}=$ Vessel diameter $(\mu \mathrm{m}), \mathrm{VF}=$ Vessel frequency $\left(\mathrm{n}^{\circ} \mathrm{mm}^{-2}\right), \mathrm{Vg}=$ Vessel grouping index (No. vessels/No. groupings), $K_{p}=$ potential hydraulic conductivity $\left(K_{p}, 10^{-6}, \mathrm{~kg} \mathrm{~m}^{-1} \mathrm{~s}^{-1} \mathrm{MPa}^{-1}\right), \mathrm{FL}=$ Fiber length $(\mu \mathrm{m}), \mathrm{FWT}=$ Fiber wall thickness $(\mu \mathrm{m}), \mathrm{RH}=\mathrm{Ray}$ height $(\mu \mathrm{m}), \mathrm{RW}=\mathrm{Ray}$ width $(\mu \mathrm{m}), \mathrm{RF}$ $=$ Ray frequency $\left(\mathrm{n}^{\circ} \mathrm{mm}^{-1}\right), \rho 12=$ Density at $12 \%$ moisture content $(\mathrm{g} \mathrm{cm}-3)$. Different letters indicate statistical significance by the Tukey test $(P$ value $<0.001$ )

Tabla 2. Características de madera de raíz, tallo y rama de Inga laurina con 10 años de edad.

Table 2. Wood features of root, stem and branch of 10-year-old Inga laurina. 

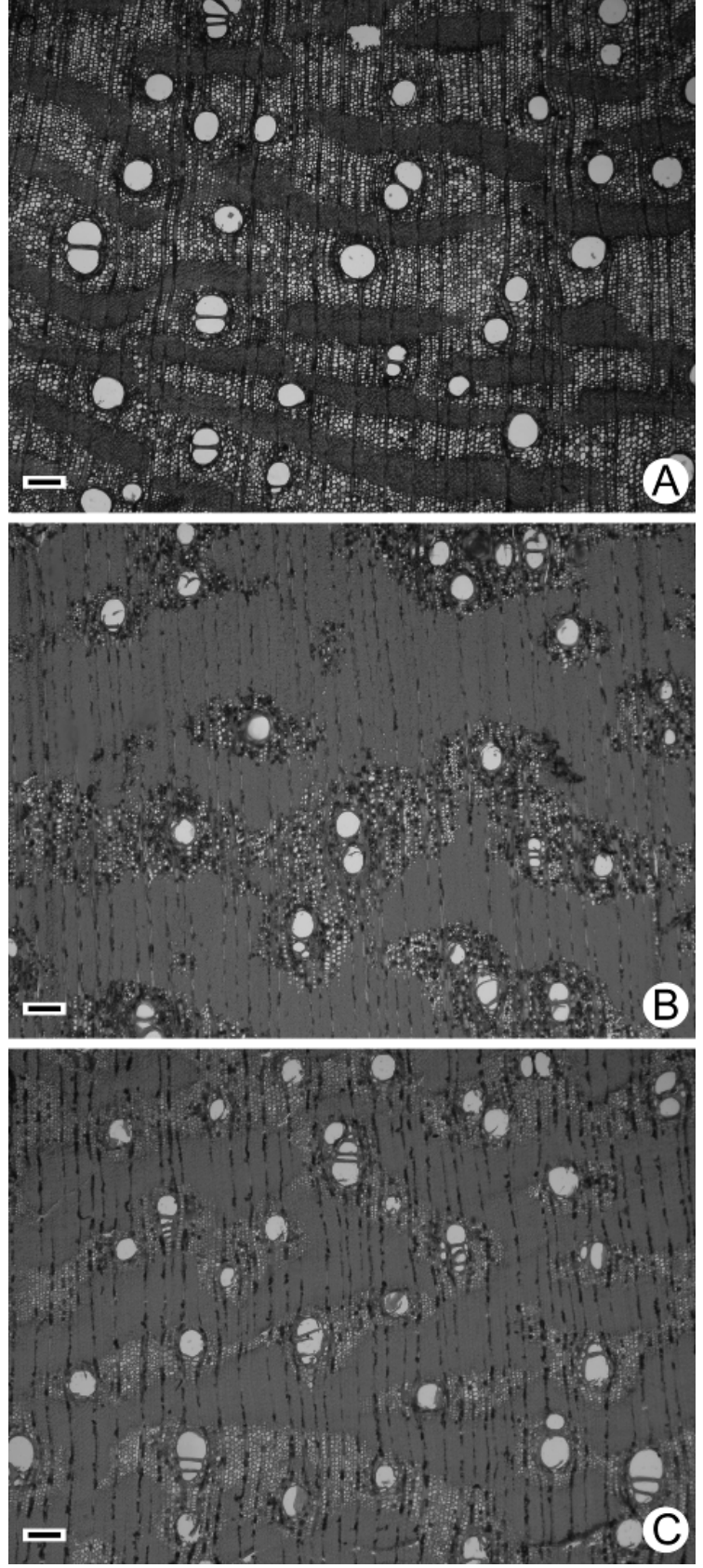

Figura 3. Secciones transversales de Inga laurina. A: raíz; B: 0,5 $\mathrm{m}$ de altura (tallo); $\mathbf{C}: 1,5 \mathrm{~m}$ de altura (rama principal). Obsérvese la mayor proporción de parénquima en la raíz y la mayor proporción de vasos múltiples en el brote. Barra de escala $=$ $150 \mu \mathrm{m}$.

Figure 3. Transverse sections of Inga laurina. A: Structure of root secondary xylem; B: Secondary xylem of main stem at $0.5 \mathrm{~m}$ above the ground level; C: Structure of secondary xylem of branch at $1.5 \mathrm{~m}$ in height (main branch). Note the higher proportion of parenchyma in the root and the higher proportion of multiple vessels in branch. Scale bar $=150 \mu \mathrm{m}$.

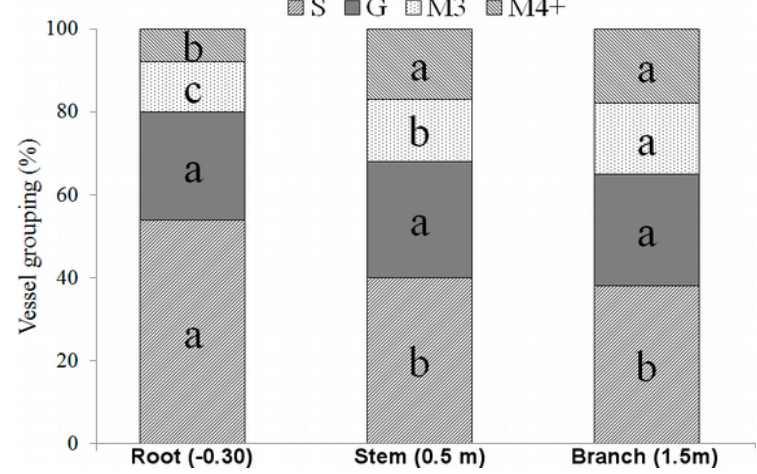

Figura 4. Variación en el agrupamiento de vasos entre la raíz, tallo y rama principal de Inga laurina con 10 años. S: solitario; G: geminato; M3: múltiplos de 3 vasos; M4+: múltiplos de 4 o más vasos. Distintas letras difieren estadísticamente por la prueba de Tukey ( $\mathrm{P}$ valor $<0,001$ ).

Figure 4. Variation in vessel grouping among the root, stem and main branch of 10-year-old Inga laurina. S: solitary; G: geminate; M3: multiples of 3 vessels; M4+: multiples of 4 or more vessels. Distinct letters differ statistically by the Tukey test (P value $<0.001$ )

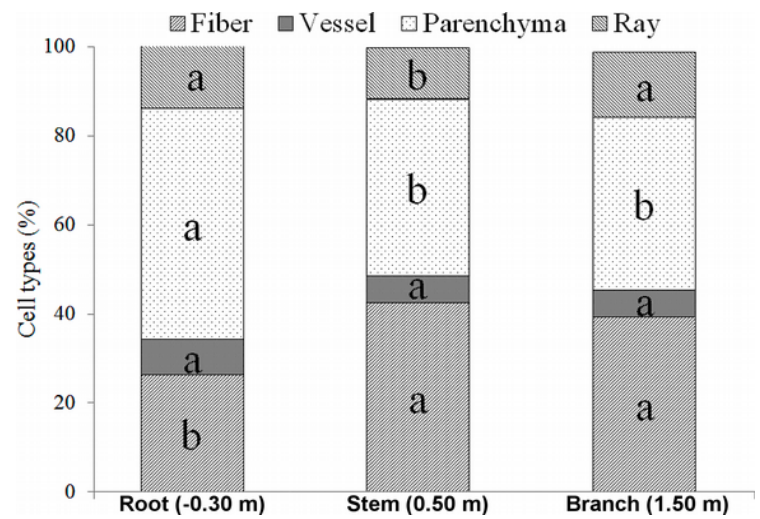

Figura 5. Variación en el porcentaje de tipo celular entre la raíz, tallo y rama principal de Inga laurina con 10 años. Distintas letras difieren estadísticamente por la prueba de Tukey (P valor $<0,001$ ). Figure 5. Variation in cell type percentage among the root, stem and main branch of 10-year-old Inga laurina. Distinct letters differ statistically by the Tukey test (P value $<0.001$ ).

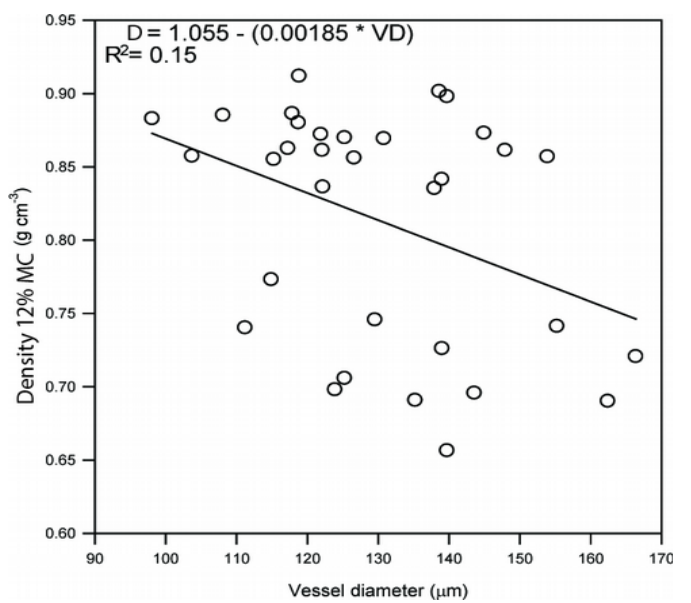

Figura 6. Regresión linear entre densidad ( $\rho 12$ ) 12\% contenido de humedad y diámetro del vaso.

Figure 6. Linear regression between density ( $\rho 12$ ) 12\% moisture content and vessel diameter. 
(2013). Typically, vessels with larger diameters are associated with higher hydraulic conductivity, which we also confirmed in I. laurina. At the same time, the root is more vulnerable to the occurrence of embolisms by its larger diameter vessels, a phenomenon corroborated by Jaquish \& Ewers (2001). Some studies reported that roots of diffuse-porous trees are potentially more vulnerable to drought-induced embolism than stems because tree roots tend to have wider vessel diameters than stems. However, the positive pressure of the roots may be effective in dissolving embolisms (Tyree \& Zimmermann 2002). Our observations are in agreement with Tyree \& Zimmermann (2002) because the percentage of parenchyma cells in the root xylem is more as compared to stem and branch. Available information indicates that storage of reserved metabolites such as starch in the parenchyma cells may be helpful in removal embolism and increase in pulling of water in vessels. According to Mooney \& Gartner (1991) and Carlquist (2001) starch is hydrolyzed in sugar and if that sugar is transported into vessels, it increases the osmotic potential. This mechanism may pull water and help in recovery of air embolism.

In addition to diameter, vessel grouping, vessel frequency and water conducting area of the secondary xylem directly affects the xylem hydraulic properties. Thus, the lower percentage of multiple vessels at the root of I. laurina may lead to increase the risk of embolism. In contrast, branch has greater wood hydraulic safety since it has a higher percentage of multiple vessels. Even though vessel grouping in branch does not differ much from the value of stem wood, we assume that the branch has higher conductive safety than the stem. According to Carlquist (1984), if one vessel in a group is disabled by an air embolism due to water stress, neighboring vessels may retain water column and the conductive pathway may be maintained intact. Under these circumstances, increasing the number of vessels in a group will increase the chance of water columns retention.

Anfodillo et al. (2013) showed an overall axial pattern in which the conduits widen from stem apex downwards in the same tree ring. This axial variation is proposed to be the most efficient anatomical adjustment for stabilizing hydraulic path-length resistance with progressive growth in height. However, depending on hydraulic/mecha- nical demands, this overall axial pattern in stem can be changed to allow adequate functioning. In the present work, we found that vessel diameter is relatively low as compared to main branch, which indicates that I. laurina does not follow the overall axial pattern, as reported by Anfodillo et al. (2013). Rowe \& Speck (2005) proposed that hydraulic safety and mechanical requirements are evolutionarily related.

In our earlier study on five native species of the Cerrado (Anadenanthera peregrina (Vell.) Brenan, Copaifera langsdorffii Desf., Handroanthus ochraceus (Chamisso) J.R. Mattos, Ocotea corymbosa (Meisn.) Mez and Xylopia aromatica (Lam.) Mart.) showed presence of hydraulic bottlenecks in the transition from the root to the stem (Longui et al. 2017). In addition, segmentation hypothesis proposed by Tyree \& Zimmermann (2002), narrower vessels at nodal zones may be related with air embolism. Therefore, we suggest that stem base protects against the risk of embolism by the presence of narrower vessels which can confine embolisms and thus protect the main stem from the constant loss of conductivity. Another explanation about embolism dynamics were reported by Dalla-Salda et al. (2014) who described for 11 years old Pseudotsuga menziesii (Mirb.) Franco trees that the size of the conduits is not directly linked with the embolism sensitivity. The authors reported that initiation and propagation of cavitation in P. menziesii seems to follow at least two successive initiation events, in which cavitation appears to initiate and propagate rapidly in the latewood, when the water deficit persists and increases, a second cavitation event begin and spread in the earlywood and eventually propagate to the transitional transition-wood, which remains the last conductive part in the ring before full cavitation. In I. laurina, we did not measure the vessels at the stem base, but rather at $0.5 \mathrm{~m}$, and the crown of trees always starts slightly above $0.5 \mathrm{~m}$. Thus, it is possible that this narrowing of the vessel diameter at $0.5 \mathrm{~m}$ from the stem may benefit water conductivity. However, further study is required to confirm conductive efficiency, since it is depending on vessel diameter, their frequency and total conducting area.

We emphasized that our results do not totally agree with WBE theoretical model (West, Brown and Enquist), which according to Anfodillo et al. (2006) WBE hypothesizes that plants developed a 
conduit network (vessels) in wood structured conically shaped, or smaller vessel diameter in distal regions of crown, and that such a structure should minimize the water transport cost from root to the leaves. Since our results show larger vessels at the root followed by branch and narrower vessels in the stem, which as discussed above, may be due to investment in mechanical strength, emphasizing that I. laurina trees have highly branched crowns and short stems. Most recent hydraulic models, such as those proposed by Savage et al. (2010) suggest that in addition to vessel tapering toward to crown, also occurs an increase in conduit number and potentially fill a constant fraction of available wood area. The model proposed by Savage $e t$ al. (2010), also does not help explain our results, although vessel frequency, was higher in shoot compared to root vessel, did not differ between the stem and branch. Perhaps, whether we had analyzed samples of top branches or more points along the height, we could establish more accurate comparisons with the proposed hydraulic models. Additionally, in our study, I. laurina trees showed small variation in height $(5.2-6.4 \mathrm{~m})$ to test the hypothesis presented by Olson et al. (2013), which affirms that plant size is by far the main driver of global variation in mean vessel diameter.

Inga laurina is found growing naturally along rivers banks and watercourses, but in the present study, the trees were planted in the climatic zone which occasionally suffer from drought, especially young plants in the months of April and August with water deficits of $(-1.6 \mathrm{~mm})$ and $(-1.2$ $\mathrm{mm})$, respectively. Thus, the wood structure with tapering vessel diameter at stem and the presence of a higher percentage of multiple vessels in main branch wood may represent an adaptation of these plants against the risk of embolisms.

It is interesting to note that I. laurina trees in general have large and low crowns when growing naturally. However, trees growing in plantation plots have shorter stems and wider crown by an average diameter of $4.5 \mathrm{~m}$ and more branches than the same tree species growing in natural environments. Longer stem in naturally growing trees may be associated with the competition for light during early part of the growth process. Walker (1991), studied tree damage and recovery from hurricane Hugo in the Luquillo Experimental Forest in Puerto Rico, and Salis et al. (2012), investigated changes in tree structure in response to strong winds in the forested areas of the Pantanal in Brazil. Both of them have observed that the fall of trees is directly related to height and stem diameter because trees with higher dimensions were uprooted in significantly larger numbers.

Light was not a limiting factor in plantation grown trees of I. laurina because all trees had adequate access to abundant light. Although we do not have wind speed data in the studied area, it can be understood that the wind is a natural effect to be considered, since the trees were planted in an open area for restoration of vegetation, thus requiring more support, in turn necessitating anatomical adjustments to meet mechanical, as well as hydraulic, demands. Therefore, structural differences are strongly correlated with the tree's mechanical properties (Niklas 1992). One of these structural differences can be seen in rays. These cells influence wood strength, and the presence of tall, wide and higher frequency of rays in stem has a positive impact on the mechanical strength of $I$. laurina trees. Mattheck \& Bethge (1994) used modeling approach and suggested that larger or more abundant rays give greater strength to wood when pulled in the radial direction. In the present study, larger and more abundant rays, fibers with thick walls and vessels with narrow diameter in stem may play a key role in the resistance of highly branched trees with wide crowns under the strong mechanical requirements during action of heavy wind and rain. As compared to roots, wood density was also greater in the stem. According to King (1986), denser woods may provide a better combination of strength and flexibility by which the secondary xylem resist rupture caused by stem stresses induced by strong winds. Negative relation between density and vessel diameter, and consequently hydraulic conductivity may be related to the biomechanical requirements, since larger vessels can contribute to the reduction of wood density (Fan et al. 2012). Badel et al. (2015) propose a different interpretation for vessel $\mathrm{x}$ wood density relation, in which increasing the stem size is an efficient option to increase rigidity, and for a given biomass in terms of construction costs, it is more relevant for the tree to build more porous, consequently wood with lower density, which generates wood with less rigidity, but a wider trunk produces a highly rigid structure and offering the mechanical requirement necessary for tree support.

Metcalfe \& Chalk (1983) reported that secondary xylem of dicotyledon root tends to have a 
higher content of ray and axial parenchyma than stem wood. Our study is in agreement with them and we noticed proportionately more axial parenchyma cells in the root, which would play an important role in the storage of sugars during periods when the plants has lower photosynthetic rate and the recovery of shoot after fire damage. Hayashi \& Appezzato-da-Glória (2009) reported that Bauhinia forficata Link, Centrolobium tomentosum Benth., Esenbeckia febrifuga (A.St.Hil.) A. Juss. ex Mart. and I. laurina trees resprout immediately after fire.

\section{Conclusions}

The results indicate that narrow vessel diameter relatively thick-walled fibers, tall and wide rays in stem may be associated with anatomical adjustments to cope up with the demands of water transport and mechanical support. At the same time, relatively thick walled fibres and less parenchyma as compared to roots seems to provide enough strength to stem to support the large crown of $I$. laurina. In contrast, roots do not have the role of mechanical support as the stem has though it has the main function of anchorage. Therefore, that could be one of the reason to have more parenchyma cells in the roots as compared to the stem tissue. The higher proportion of parenchyma cells in the root, which affords the capacity to store starch, which is important for shoot recovery after fire damage (a characteristic of the Cerrado forest), as well as during periods of low photosynthetic activity when previously stored starch can be mobilized. Moreover, during dryer period starch stored in the root parenchyma may be playing important role to increase the osmotic potential for the absorption of water and protect the vessels from embolism in response less availability of ground water.

\section{Acknowledgements}

The authors thank Sonia G. Campião, Yara R. W. Vianello and Juraci A. Barbosa for laboratory assistance and Israel L. de Lima for field assistance. Thanks, are also due to both the anonymous reviewers and Editor in chief for their valuable comments on the previous version of the manuscript.

\section{References}

Abrantes J, Campelo F, García-González I \& Nabais C. 2013. Environmental control of vessel traits in Quercus ilex under Mediterranean climate: relating xylem anatomy to function. Trees 27: 655-662.

Anfodillo T, Carraro V, Carrer M, Fior C \& Rossi S. 2006. Convergent tapering of xylem conduits in different woody species. New Phytologist 169: 279-290.

Anfodillo T, Petit G \& Crivellaro A. 2013. Axial conduit widening in woody species: a still neglected Anatomical pattern. IAWA Journal 34: 352-364.

Awad $\mathrm{H}$, Herbette $\mathrm{S}$, Brunel $\mathrm{N}$, Tixier A, Pilate G, Cochard H 6 Badel E. 2012. No trade-off between hydraulic and mechanical properties in several transgenic poplars modified for lignins metabolism. Environmental and Experimental Botany 77: 185195.

Baas P, Ewers FW, Davis SD \& Wheeler EA. 2004. Evolution of xylem physiology. In: Evolution of Plant Physiology (Poole I \& Hemsley A, eds). Elsevier Academic Press (Linnaean Society Symposium Series), pp 273-295.

Badel E, Ewers FW, Cochard H \& Telewski FW. 2015. Acclimation of mechanical and hydraulic functions in trees: Impact of the thigmomorphogenetic process. Frontiers in Plant Science 6: 266. doi: 10.3389/ fpls.2015.00266

Berlyn GP \& Miksche JP. 1976 Botanical microtechnique and cytochemistry. lowa City: The lowa University Press.

Bognola IA, Prado H, Menk JRF, Joaquim AC \& Lepsch IF. 2003. Levantamento pedológico semidetalhado do Estado de São Paulo: Quadrícula de Assis. II. Memorial Descritivo. Série Pesquisa APTA. Boletim de Pesquisa 08. Campinas: Instituto Agronômico.

Carlquist S. 1984. Vessel grouping in dicotyledon wood: significance and relationship to imperforate tracheary elements. Aliso 10: 505-525.

Carlquist S. 2001. Comparative wood anatomy: systematic, ecological and evolutionary aspects of dicotyledon wood (2edn). Springer Verlag.

CEPAGRI (Centro de pesquisas meteorológicas e climáticas aplicadas à agricultura) 2016. Clima dos Municípios Paulistas. Available at http://www.cpa.unicamp.br/outras-informacoes/clima-dosmunicipiospaulistas.html. [accessed 6 March 2017].

Dalla-Salda G, Fernández ME, Sergent AS, Rozenberg P, Badel E \& Martinez-Meier A. 2014. Dynamics of cavitation in a Douglas-fir tree-ring: transition-wood, the lord of the ring? Journal of Plant Hydraulics, INRA Editions, 1, pp.e0005. Doi: 10.20870/ jph.2014.e005

Fan ZX, Zhang SB, Hao GY, Ferry Slik JW \& Cao KF. 2012. Hydraulic conductivity traits predict growth rates and adult stature of 40 Asian tropical tree species better tan wood density. Journal of Ecology 100: 732-741.

Garcia FCP \& Fernandes JM. 2014. Inga in Lista de Espécies da Flora do Brasil. Jardim Botânico do Rio de Janeiro. Available at http://floradobrasil.jbrj.gov.br/ jabot/floradobrasil/FB23007. [accessed 10 January 
2014].

Garcia FCP. 1998. Relações Sistemáticas e Fitogeografia de Inga Mill. (Leguminosae- Mimosoideae) nas florestas da costa sul e sudeste do Brasil. Tese de doutorado, Universidade Estadual Paulista (UNESP), Brasil.

Gartner BL. 1995. Patterns of xylem variation within a tree and their hydraulic and mechanical consequences. In: Gartner BL (ed), Plant stems: Physiology and functional morphology. Academic Press. pp 125-149.

Glass S \& Zelinka SL. 2010. Moisture Relations and Physical Properties of Wood. In: Ross R (ed), Wood Handbook, Centennial Edition. FPL-GTR-190. U.S. Department of Agriculture, Forest Service, Forest Products Laboratory. pp 4.1-4.19.

Hayashi AH \& Appezzato-da-Glória B. 2009. Resprouting from roots in four Brazilian tree species. International Journal of Tropical Biology 57: 789-800.

Hinckley TM, Lachenbruch B, Meinzer FC \& Dawson TE. 2011. A Lifespan Perspective on Integrating Structure and Function in Trees. In: Meinzer FC, Lachenbruch B, Dawson TE (eds), Size and age-related changes in tree structure and function. Springer. pp 03-30.

IAWA Committee. 1989. IAWA list of microscopic features for hardwood identification. IAWA Bulletin n.s. 10: 219-332.

Jaquish LL \& Ewers FW. 2001. Seasonal conductivity and embolism in the roots and stems of two clonal ring-porous trees, Sassafras albidum (Lauraceae) and Rhus typhina (Anacardiaceae). American Journal of Botany 88: 206-212.

King DA. 1986. Tree form: Height growth, and susceptibility to wind damage in Acer saccharum. Ecology 67: 980-990.

Longui EL, Rajput KS, Melo ACG, Alves LA \& Nascimento CB. 2017. Root to branch wood anatomical variation and its influence on hydraulic conductivity in five Brazilian Cerrado species. Bosque 38(1): 183-193, 2017

Mattheck C \& Bethge K. 1994. A guide to fractometer tree assessment. Arborist's News 3: 9-12.

Max JCM, Melo ACG, Honda EA, Durigan G, Malícia LC, Souza MBM, Cardoso MM, Bôas OV, Ramos VS \& Contiéri WA. 2007. Plano de manejo da Floresta Estadual de Assis. IF Série Registros 30: 1-80.

Metcalfe CR \& Chalk L. 1983. Anatomy of the dicotyledons: wood structure and conclusion of the general introduction (2edn). Oxford: Oxford University Press.

Mooney HA \& Gartner BL. 1991. Reserve economy of vines. In: The biology of vines (Putz FE, Mooney HA, eds.). Cambridge: Cambridge University Press. pp 166-179.

Niklas KJ. 1992. Plant biomechanics: an engineering approach to plant form and function. University of
Chicago Press.

Olson ME \& Rosell JA. 2013 Vessel diameter-stem diameter scaling across woody angiosperms and the ecological causes of xylem vessel diameter variation. New Phytologist 197: 1204-1213.

Pennington TD. 1997. The genus Inga: botany. Kew, Royal Botanic Garden.

Poorter L, McDonald I, Alarcón A, Fichtler E, Licona J, Peña-Claros M, Sterck F, Villegas Z \& SassKlaassen U. 2010. The importance of wood traits and hydraulic conductance for the performance and life history strategies of 42 rainforest tree species. New Phytologist 185: 481-492.

Pratt RB, North GB, Jacobsen AL, Ewers FW \& Davis SD. 2010. Xylem root and shoot hydraulics is linked to life history type in chaparral seedlings. Functional Ecology, 24: 70-81.

Robert EMR, Koedam N, Beeckman H \& Schmitz N. 2009. A safe hydraulic architecture as wood anatomical explanation for the difference in distribution of the mangroves Avicennia and Rhizophora. Functional Ecology 23: 649-657.

Rowe N \& Speck T. 2005. Plant growth forms: an ecological and evolutionary perspective. New Phytologist 166: 61-72.

Salis SM, Lehn CR, Padilha DRC \& Mattos PP. 2012. Changes in the structure due to strong winds in forest areas in the Pantanal, Brazil. Cerne 18: 387395.

Scholz A, Klepsch M, Karimi Z \& Jansen S. 2013. How to quantify conduits in wood? Frontiers in Plant Science 4: 1-11.

Schuldt B, Leuschner CH, Brock N \& Horna V. 2013. Changes in wood density, wood anatomy and hydraulic properties of the xylem along the root-toshoot flow path in tropical rainforest trees. Tree Physiology 33: 161-174.

Sousa JS, Bastos MNC \& Gurgel ESC. 2011. O gênero Inga (Leguminosae-Mimosoideae) na Província Petrolífera de Urucu, Coari, Amazonas, Brasil. Rodriguésia 62: 283-297.

Sterck FJ, Zweifel R, Sass-Klaassen U \& Chowdhury Q. 2008. Persisting soil drought reduces leaf specific conductivity in Scots pine (Pinus sylvestris) and pubescent oak (Quercus pubescens). Tree Physiology 28: 529-536.

Tyree MT \& Zimmerman MH. 2002. Xylem structure and the ascent of sap. Springer.

von Arx G, Archer SR \& Hughes MK. 2012. Long-term functional plasticity in plant hydraulic architecture in response to supplemental moisture. Annals of Botany 109: 1091-1100.

Walker L.R. 1991. Tree damage and recovery from hurricane Hugo in Luquillo experimental forest, Puerto Rico. Biotropica 24: 379-385. 